\title{
Development of proton-conducting membrane based on incorporating a proton conductor 1,2,4-triazolium methanesulfonate into the Nafion membrane
}

\author{
Jinkai $\mathrm{Hao}^{\mathrm{a}, \mathrm{b}}, \quad$ Xiaojin $\mathrm{Li}^{\mathrm{a} *}$, Shuchun $\mathrm{Yu}^{\mathrm{a}, \mathrm{b}}$, Yongyi Jianga,b, \\ Jiangshui Luo ${ }^{\mathrm{c}, \mathrm{d}}$, Zhigang Shao ${ }^{\mathrm{a} *}$, Baolian $\mathrm{Yi}^{\mathrm{a}}$ \\ a. Fuel Cell System and Engineering Laboratory, Dalian Institute of Chemical Physics, Chinese Academy of Sciences, Dalian 116023, Liaoning, China; \\ b. University of Chinese Academy of Sciences, Beijing 100039, China; \\ c. Department of Materials Engineering, KU Leuven, Leuven 3001, Belgium; \\ d. Centre for Surface Chemistry and Catalysis, KU Leuven, Leuven 3001, Belgium
}

[ Manuscript received September 28, 2014; revised November 3, 2014]

\begin{abstract}
In this paper, 1,2,4-triazolium methanesulfonate $\left(\mathrm{C}_{2} \mathrm{H}_{4} \mathrm{~N}_{3}^{+} \mathrm{CH}_{3} \mathrm{SO}_{3}^{-}\right.$, [Tri][MS]), an ionic conductor, was successfully synthesized. It exhibited high ionic conductivity of $18.60 \mathrm{mS} \cdot \mathrm{cm}^{-1}$ at $140^{\circ} \mathrm{C}$ and reached up to $36.51 \mathrm{mS} \cdot \mathrm{cm}^{-1}$ at $190{ }^{\circ} \mathrm{C}$. [Tri][MS] was first applied to modify Nafion membrane to fabricate [Tri][MS]/Nafion membrane by impregnation method at $150{ }^{\circ} \mathrm{C}$. The prepared composite membrane showed high thermal stability with decomposed temperature above $200^{\circ} \mathrm{C}$ in air atmosphere. In addition, the membrane indicated good ionic conductivity with $3.67 \mathrm{mS} \cdot \mathrm{cm}^{-1}$ at $140{ }^{\circ} \mathrm{C}$ and reached up to $13.23 \mathrm{mS} \cdot \mathrm{cm}^{-1}$ at $180{ }^{\circ} \mathrm{C}$. The structure of the [Tri][MS] and the composite membrane were characterized by FTIR and the compatibility of [Tri][MS] and Pt/C catalyst was studied by a cyclic voltammetry (CV) method. Besides, the [Tri][MS]/Nafion membrane (thickness of $65 \mu \mathrm{m}$ ) was evaluated with single fuel cell at high temperature and without humidification. The highest power density of [Tri][MS]/Nafion membrane was $3.20 \mathrm{~mW} \cdot \mathrm{cm}^{-2}$ at $140^{\circ} \mathrm{C}$ and $4.90 \mathrm{~mW} \cdot \mathrm{cm}^{-2}$ at $150{ }^{\circ} \mathrm{C}$, which was much higher than that of Nafion membrane.
\end{abstract}

Key words

high temperature PEMFC; membranes; triazole; Nafion; ionic conductor

\section{Introduction}

High temperature proton exchange membrane fuel cell (HT-PEMFC), enhanced electrode electrochemical kinetics, simplified water management and the cooling system, and increased CO tolerance, has been widely investigated recently [1-5]. Proton exchange membrane (PEM) is one of the key components in high temperature PEMFC, whose function is to conduct proton and separate reactants. With high proton conductivity, the perflurinated sulfonic membranes like Nafion are widely applied in PEMFC. However, the proton conductivity of the traditional membrane is seriously dependent on water present in membrane [6]. The membrane will be dehydrated with temperature above the boiling temperature of water decreasing the proton conductivity and further degrading the fuel cell performance. As a result, development of high temperature proton exchange membranes with high proton conductivity, high chemical and mechanical stability, and low permeability to fuel is the core obstacle in high temperature PEMFCs and has attracted much interest [7-9]. To improve the performance of Nafion ${ }^{\circledR}$ membranes for PEMFC in high temperature and no-humidification conditions, many researchers try modified membrane using various methods. An effective approach is incorporating Nafion membrane with protonic ionic liquids (PILs) [10-13]. PILs, as a kind of non-aqueous proton-conducting electrolyte with low volatility and relatively high ionic conductivity, are formed by proton transfer between Brønsted acids and bases. Noda [14] introduced imidazole into PEMFC firstly. Henceforth, great attentions have been paid to ILs and composite membranes contained ILs and polymer electrolyte such as imidazole, triazole, and tetrazole [15]. Doyle et al. [16] reported the influence

* Corresponding authors. Tel: +86-411-84379123; Fax: +86-411-84379185; E-mail: xjli@dicp.ac.cn; Tel: +86-411-84379153; Fax: +86-411-84379185; E-mail: zhgshao@dicp.ac.cn

This work was financially supported by the National Basic Research Program of China (973 Program, Grant 2012CB215504) and the National Natural Science Foundation of China (21203191 and 21306190). 
between Nafion membranes and ILs and immersed 3-methyl imidazolium triflate (MNI-Tf) into Nafion membranes. The ionic conductivity of the composite membrane exhibited $6 \times 10^{-2} \mathrm{~S} \cdot \mathrm{cm}^{-1}$ and $1 \times 10^{-1} \mathrm{~S} \cdot \mathrm{cm}^{-1}$ between 150 and $180^{\circ} \mathrm{C}$. Yang et al. [17] fabricated a composite membrane Nafion/BMIm/PA based on Nafion115, ionic liquid and phosphoric acid and the membrane had potential to be used in the high temperature PEMFC with a tensile stress at break of $5.3 \mathrm{MPa}$ and a proton conductivity of $10.9 \mathrm{mS} \cdot \mathrm{cm}^{-1}$ at $160^{\circ} \mathrm{C}$ without humidification. Sevim et al. [18] fabricated a new copolymer doped with $\mathrm{H}_{3} \mathrm{PO}_{4}$ based on 1-vinyl-1,2,4triazole (VTri) and diisopropyl-p-vinylbenzyl phosphonate (VBP), which showed a proton conductivity of $0.005 \mathrm{~S} \cdot \mathrm{cm}^{-1}$ at $150{ }^{\circ} \mathrm{C}$. To improve the compatibility of Nafion-TEA membranes, Iojoiu et al. [19] doped Trifluoromethanesulfonate of triethylamm-monium (TFTEA) into Nafion-TEA. By casting they fabricated Nafion-TEA membrane containing $20 \mathrm{wt} \%$ TFTEA. Under $100{ }^{\circ} \mathrm{C}, 100 \% \mathrm{RH}$ (relative humidity), and $1 \mathrm{~atm}$ relative pressure, current density of fuel cell reached $0.85 \mathrm{~A} / \mathrm{cm}^{2}$ at $0.6 \mathrm{~V}$. However, it was pity that no corresponding data about high temperature and no-humidifying conditions.

Triazole has three nitrogens in the ring and has similar proton-transfer mechanism with imidazole [20]. Moreover, the proton can be transferred easier than imidazole due to the structure of single-double alternated bond and three nitrogens in the ring of triazole. And the chemical stability and the ability of ionic transform of triazole are better than imidazole. $1 \mathrm{H}-1,2,4$-triazole is a potentially useful heterocycle which has a relatively high proton conductivity up to $1.2 \times 10^{-3} \mathrm{~S} \cdot \mathrm{cm}^{-1}$ at its melting point [21]. Luo et al. [22] prepared 1,2,4-triazolium methanesulfonate $\left(\mathrm{C}_{2} \mathrm{H}_{4} \mathrm{~N}_{3}^{+} \mathrm{CH}_{3} \mathrm{SO}_{3}^{-}\right)$using $1 \mathrm{H}-1,2,4$-triazole $\left(\mathrm{C}_{2} \mathrm{H}_{3} \mathrm{~N}_{3}\right)$ and methanesulfonic acid $\left(\mathrm{CH}_{3} \mathrm{SO}_{3} \mathrm{H}\right)$. The resulting of its thermal property, proton conduction behaviour and electrochemical stability suggested 1-methanesulfon-1,2,4-triazol would be a suitable candidate for high temperature PEMFC electrolytes.

In this paper, a ionic conductor of 1,2,4-triazolium methanesulfonate ([Tri]][MS]) was synthesized and was first to be applied to incorporate into Nafion membrane to fabricate Nafion/[Tri][MS] composite membrane by impregnation method. The structural, thermal and electrochemical properties of the composite membranes were investigated. Moreover, fuel cell performance at high temperature and the compatibility between [Tri][MS] and Pt/C catalyst were systematically explored.

\section{Experimental}

\subsection{Materials}

$1 \mathrm{H}-1,2,4$-triazol (Tri, 99.5\%) was supplied from ACROS Co., USA, methanesulfonic acid (MSA, 98\%) from Tianjin Guangfu Fine Chemical Research Institute, the Nafion (NRE212) membrane from DuPont, USA. N-methyl-2pyrrolidone (NMP, >99\%) and methanol $(99.9 \%, \mathrm{AR})$ were purchased from Tianjing kemiou Chemical Ltd, China. Acetone (DMK, >99.5\%) was supplied from Dalian inorganic chemical Co. Besides, polybenzimidazole (PBI), used in the gas diffusion electrode (GDE), was synthesized as reported previously [9]. Pt/C (70\% Pt on Vulcan XC-72 carbon) was purchased from Johnson Matthey.

\subsection{Fabrication of 1,2,4-triazolium methanesulfonate ([Tri][MS])}

The [Tri] $[\mathrm{MS}]$ was synthesized from methanesulfonic acid (MSA) and 1H-1,2,4-triazol (Tri) by acid-base neutralization reaction. Firstly, Tri was dissolved with acetone and stirred to get transparent solution of Tri. Then, the MSA was added into the solution dropwise, which was stirred for $4 \mathrm{~h}$. Herein, the mole ratio of MSA and Tri was $1: 1.5$. The produced white particles was washed several times with acetone to remove residual MSA and dried at $60{ }^{\circ} \mathrm{C}$ to obtain purified [Tri] [MS] $\left(\mathrm{C}_{2} \mathrm{H}_{4} \mathrm{~N}_{3}^{+} \mathrm{CH}_{3} \mathrm{SO}_{3}^{-}\right)$.

\subsection{Preparation of the [Tri][MS]/Nafion membrane}

The [Tri][MS]/Nafion composite membrane was prepared as follows. Firstly, the Nafion (NRE212) membrane was dried in the vacuum drying oven at $80^{\circ} \mathrm{C}$ for $2 \mathrm{~h}$. Then, the Nafion ${ }^{\circledR}$ membranes were immersed into [Tri][MS]-saturated methanol solution at $60^{\circ} \mathrm{C}$ for $12 \mathrm{~h}$ and dried for $12 \mathrm{~h}$. Put the above membranes into molten [Tri][MS] at $150^{\circ} \mathrm{C}$ for $7 \mathrm{~h}$ and $36 \mathrm{~h}$, respectively, to make the membrane saturated with [Tri][MS] (marked by the [Tri][MS]/Nafion membrane$7 \mathrm{~h}$, the [Tri][MS]/Nafion membrane-36 h). Finally, the residual melt [Tri][MS] on the surface of the membrane was scraped off with filter paper at $150{ }^{\circ} \mathrm{C}$ and dried to obtain the $[$ Tri] $][\mathrm{MS}] /$ Nafion composite membrane. The content of [Tri][MS] in the [Tri][MS]/Nafion membrane-36 $\mathrm{h}$ was $25 \mathrm{wt} \%$. By comparison, the content of [Tri][MS] of the [Tri][MS]/Nafion membrane-7 h was $8 \mathrm{wt} \%$.

\subsection{Physical characterization}

Fourier-transform infrared (FTIR) of [Tri] [MS] and the [Tri][MS]/Nafion membrane was recorded with a Bruker Equinox 55 FTIR spectrometer. The thermal stability was measured by thermogravimetric analysis (TGA, STA449F3, NETZSCH, Germany) at the rate of $10^{\circ} \mathrm{C} \cdot \mathrm{min}^{-1}$ under air and $\mathrm{N}_{2}$ atmosphere. Differential scanning calorimetry (DSC) was carried out on a Seiko Instrument DSC 811 under air atmosphere. The sample was heated to $200^{\circ} \mathrm{C}$ and then cooled to ambient temperature and heated again to $200^{\circ} \mathrm{C}$ at the rate of $10^{\circ} \mathrm{C} \cdot \mathrm{min}^{-1}$. The morphology of the [Tri][MS]/Nafion membrane was observed with a field emission scanning electron microscopy (FESEM; Hitachi, S-4800).

\subsection{Ionic conductivities}

The ionic conductivity of [Tri][MS] was measured by the conductivity meter (DSA-11, Shanghai LEI-CI Co. Ltd, 
China) in the range of $140{ }^{\circ} \mathrm{C}$ to $190{ }^{\circ} \mathrm{C}$. In order to minimize experimental error, the experiment system was stable at each temperature for $2 \mathrm{~h}$ before measurements. The in-plane ionic conductivities of the [Tri][MS]/Nafion membrane were determined by the 2-probe DC method (a Solartron S1 1260 analyzer) over a frequency range from $10^{6}$ to $100 \mathrm{~Hz}$ at a voltage amplitude of $10 \mathrm{mV}$ under no humidification. In this measurement, the membrane was cut into $1 \mathrm{~cm} \times 4 \mathrm{~cm}$ and pressed on two platinum-wired electrodes (the distance between the electrodes was $2 \mathrm{~cm}$ ), and the electrodes and membrane were pressed between two stainless-steel plates and clamped tightly by four bolts. The chamber was then placed in a vacuum oven and measured in the range of $130^{\circ} \mathrm{C}$ to $180^{\circ} \mathrm{C}$.

The ionic conductivity $(\sigma)$ of the membrane was calculated by the following equation [23].

$$
\sigma=\frac{L}{R d w}
$$

where, $L$ was the distance of the two platinum electrodes, $R$ was the membrane resistance by the impedance value at 0 phase angle, and $d$ and $w$ were the thickness and width of the [Tri][MS]/Nafion membrane, respectively.

\subsection{Electrochemical characterization}

To examine the effect of [Tri][MS] on the performance of $\mathrm{Pt} / \mathrm{C}$ catalyst, the cyclic voltammetry $(\mathrm{CV})$ and the $\mathrm{O}_{2}$ reduction reaction (ORR) curves of $\mathrm{Pt} / \mathrm{C}$ electrode and the $\mathrm{Pt} / \mathrm{C}$ electrode dyed with [Tri][MS] were measured. All the measurements were conducted at CHI 730 electrochemical workstation with a three-electrode system using a rotating ring disk electrode (RRDE, PINE AFE7R9GCPT) and saturated calomel electrode (SCE) as the reference and counter electrodes, respectively. And the rotating ring disk electrode was made of a ring made of platinum $(6.25 \mathrm{~mm}$ inner diameter and $7.92 \mathrm{~mm}$ outer diameter) and a glassy carbon disk (5.61 mm diameter). $5 \mathrm{mg} \mathrm{Pt/C} \mathrm{(40} \mathrm{wt \% ,} \mathrm{Johnson} \mathrm{Matthey),}$ $50 \mu \mathrm{L}$ Nafion solution (5 wt\%) and $1 \mathrm{~mL}$ isopropyl alcohol were dispersed ultrasonically and $4 \mu \mathrm{L}$ ink was transferred onto the glassy carbon electrode. The catalyst loading was $31 \mu \mathrm{g} \cdot \mathrm{cm}^{-2}$. The $\mathrm{CV}$ curve was measured in $0.5 \mathrm{~mol} / \mathrm{L}$
$\mathrm{H}_{2} \mathrm{SO}_{4}$ saturated with $\mathrm{N}_{2}$ at the rate of $50 \mathrm{mV} \cdot \mathrm{s}^{-1}$ from -0.241 to $0.959 \mathrm{~V}$ (vs. SCE). In RRDE tests, the ring potential was $1.15 \mathrm{~V}$ in order to oxidize the hydrogen peroxide produced during oxygen reduction.

\subsection{Membrane electrode assembly (MEA) fabrication and single-cell tests}

The ionomer-PBI gas diffusion electrode (GDE) was used in this study, which was prepared as reported previously [9]. The catalyst ink of GDE included (Pt/C), PBI and polyvinylidene fluoride (PVDF) $(230: 12: 7, \mathrm{w} / \mathrm{w})$ [24]. The [Tri][MS]/Nafion composite membrane (thickness of $65 \mu \mathrm{m}$ ) was sandwiched between two GDEs by hot pressing $\left(140^{\circ} \mathrm{C}\right)$ to form the membrane electrode assembly (MEA). The active area of electrode was $5 \mathrm{~cm}^{2}$ and Pt loading was $0.5 \mathrm{mg} \cdot \mathrm{cm}^{-2}$. The MEA was tested in a single cell with the operating temperature of 140 and $150{ }^{\circ} \mathrm{C}$. $\mathrm{H}_{2}$ and $\mathrm{O}_{2}$ gases were supplied to the cell at pressure of $0.05 \mathrm{MPa}$ at constant flow rates $\left(\mathrm{H}_{2} / \mathrm{O}_{2}=30 \mathrm{~mL} \cdot \mathrm{min}^{-1}\right)$ with no humidification. The fuel cell polarization curve was recorded by an electronic load PLZ50F (Kikusui, Japan).

\section{Results and discussion}

\subsection{The feature of the [Tri][MS]/Nafion membrane}

The 1,2,4-triazolium methanesulfonate ([Tri][MS]) was synthesized from 1H-1,2,4-triazol and methanesulfonic acid and was characterized by FTIR. The chemical structure was shown in Figure 1. The [Tri][MS]/Nafion composite membrane was prepared by impregnation method under high temperature and the content of [Tri][MS] could reached up to $25 \mathrm{wt} \%$. SEM images (Figure 2) showed the surface and

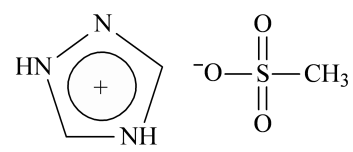

Figure 1. Chemical structure of 1,2,4-triazolium methanesulfonate
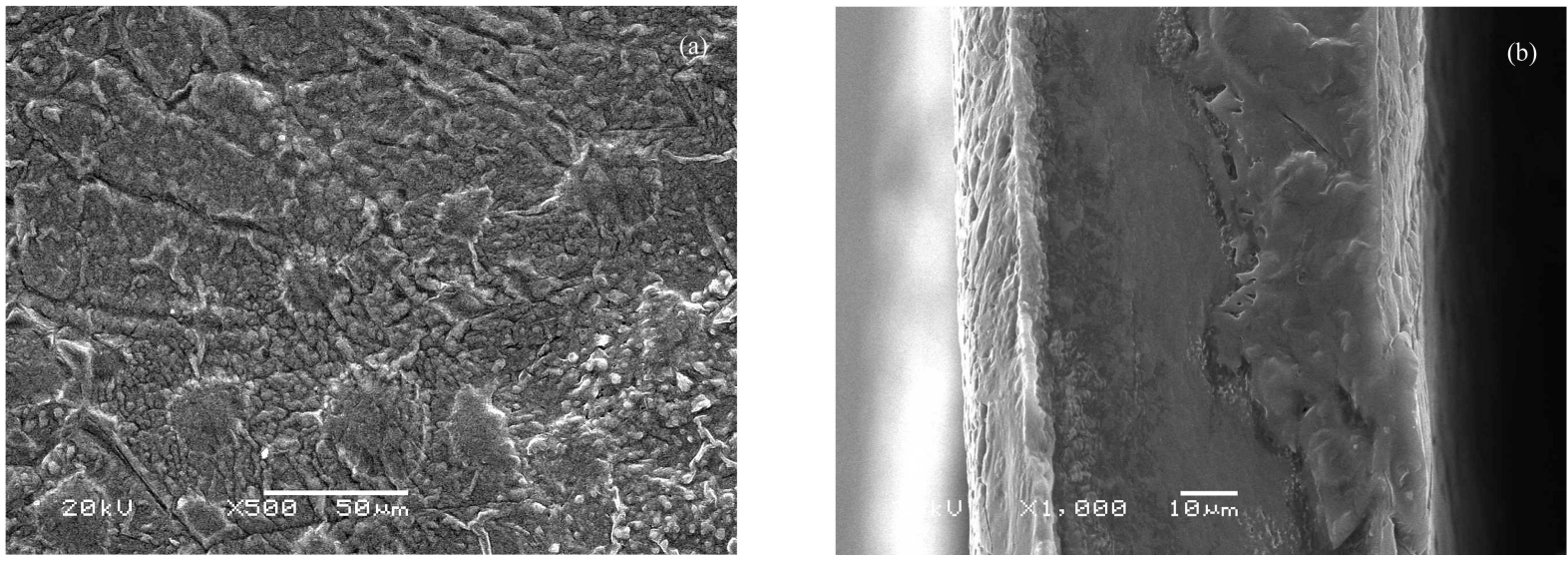

Figure 2. SEM images of surface (a) and cross-section (b) of [Tri][MS]/Nafion membrane-36 h 
cross-section morphologies of the [Tri][MS]/Nafion membranes. The surface of composite membranes showed a homogeneous dispersed morphology and the cross-section views of composite membranes looked dense and uniform. Besides, in the experiment of fabricating membranes, many polymers were tried, such as PBI, PVDF and SPEEK. However, it was difficult to fabricate a homogeneous phase membrane by mixing [Tri][MS] with these polymers directly because of the poor compatibility between [Tri][MS] and polymers.

\subsection{FTIR results of [Tri]][MS] and [Tri][MS]/Nafion mem- branes}

FTIR spectra of [Tri][MS] and the [Tri][MS]/Nafion membrane were shown in Figure 3. In FTIR spectra of [Tri][MS] (Figure 3a), the absorption bands appearing at $1569 \mathrm{~cm}^{-1}$ and $3134 \mathrm{~cm}^{-1}$ were attributed to the protonation of the triazole rings $[25,26]$. And the absorption bands at 2888,2796 and $2611 \mathrm{~cm}^{-1}$ should be related to associate $\mathrm{NCH}$ stretching vibrations in the protonated triazole rings [27]. Furthermore, the medium $\mathrm{C}-\mathrm{N}$ stretching peak at $1531 \mathrm{~cm}^{-1}$ and the absence of $\mathrm{C}=\mathrm{N}$ stretching peak at $1544 \mathrm{~cm}^{-1}$ were attributed to the proton exchange reactions $[28,29]$. Besides, the sharp absorption bands at $1041 \mathrm{~cm}^{-1}$ was associated with the $\mathrm{SO}_{3}$ symmetric stretching vibration of $\mathrm{CH}_{3} \mathrm{SO}_{3}^{-}$[26]. The absorption of the $\mathrm{SO}_{3}$ symmetric stretching vibration of $\mathrm{CH}_{3} \mathrm{SO}_{3}^{-}$around 1195 and $1218 \mathrm{~cm}^{-1}$ was characteristic for a $\mathrm{CH}_{3} \mathrm{SO}_{3}^{-}$anion strongly involved in a hydrogen bond. The other IR spectra absorption bands of $\mathrm{CH}_{3} \mathrm{SO}_{3}^{-}$appeared at $776 \mathrm{~cm}^{-1}$ (S-C stretch) and $1411 \mathrm{~cm}^{-1}$ $\left(\mathrm{CH}_{3}\right.$ asymmetric deformation) [22]. Meanwhile, $882 \mathrm{~cm}^{-1}$ was attributed to the $\mathrm{C}-\mathrm{H}$ out-of-plane bend [30]. FT-IR spectroscopic analysis results demonstrated the structure of [Tri][MS] (shown in Figure 1).

The [Tri][MS]/Nafion membrane-36 $\mathrm{h}$ and membrane-7 $\mathrm{h}$ exhibited the same medium absorption at $1569 \mathrm{~cm}^{-1}$ which

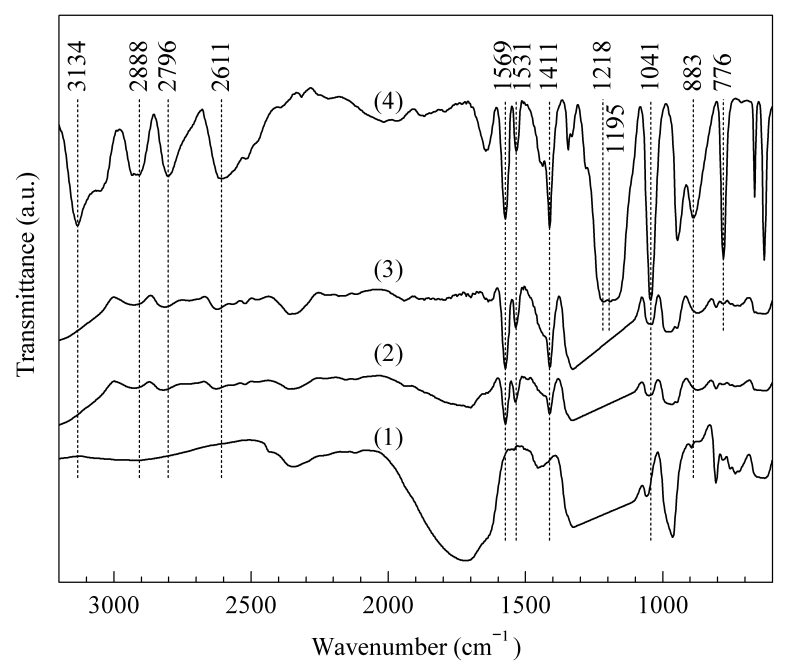

Figure 3. FTIR spectra of membranes. (1) Nafion 212-0 h, (2) [Tri][MS]/Nafion membrane-7 h, (3) [Tri]][MS]/Nafion membrane-36 h, (4) [Tri][MS] was attributed to the protonation of the triazole rings [22] and the intensity of the peak increased with the increased amount of [Tri][MS] in membrane. The peaks of $\mathrm{N}-\mathrm{H}$ stretching vibrations in the protonated triazole rings at 2888, 2796 and $2611 \mathrm{~cm}^{-1}$ appeared in the [Tri][MS]/Nafion membranes and indicated that the [Tri][MS] was impregnated in the Nafion membrane.

\subsection{Thermal properties}

An important criterion of protonic conductor and polymer based membranes for fuel cells at high temperature was their thermal stabilities [31], which was investigated with TGA and DSC. The TGA curves of the pure [Tri][MS] and [Tri][MS]/Nafion composite membrane were indicated in Figure 4 . It can be clearly seen that the decomposed temperature of [Tri][MS] was greater than $200{ }^{\circ} \mathrm{C}$ in nitrogen atmosphere, which was sufficient for the operation of HT-PEMFC. In air atmosphere, the TG curve profile of [Tri][MS] was similar to that in nitrogen atmosphere.

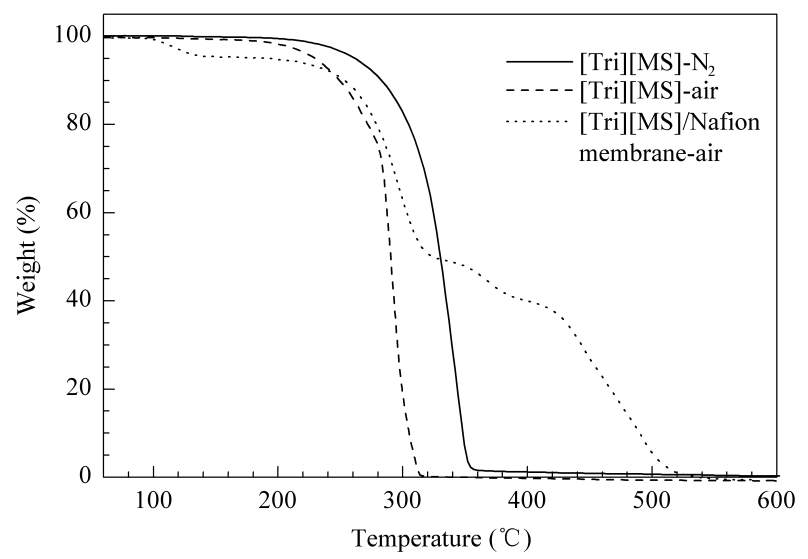

Figure 4. TGA patterns of composite membranes and [Tri][MS] under air and nitrogen atmospheres

As for the Nafion membrane, there existed three weight loss stages in the entire of decomposition [32], while there were four weight loss stages during the decomposition of [Tri][MS]/Nafion composite membrane as illustrated in Figure 4 . The $4.71 \%$ weight loss of the [Tri][MS]/Nafion membrane at the temperature of about $100{ }^{\circ} \mathrm{C}$ was ascribed to water loss. The second stage of the $46.03 \%$ weight loss at the temperature from 200 to $320^{\circ} \mathrm{C}$ corresponded to the decomposition of [Tri][MS], which did not exist in the pure Nafion membrane [33]. The third one of the $9.27 \%$ weight loss between 320 and $400{ }^{\circ} \mathrm{C}$ was caused by the elimination of the sulfonate groups in the matrix polymer and the last one of the $40.84 \%$ weight loss between 400 and $520^{\circ} \mathrm{C}$ was due to the oxidative destruction of the perfluorinated matrix. These results demonstrated that the [Tri][MS]/Nafion membrane had distinct thermal stability to be used at high temperatures fuel cells $\left(100-200^{\circ} \mathrm{C}\right)$.

Figure 5 shows the DSC thermograms of the [Tri][MS]/Nafion membrane, the Nafion membrane and the 
pure [Tri][MS]. It can be seen that the DSC thermogram of the pure [Tri][MS] showed an endothermic peak at $136^{\circ} \mathrm{C}$, which corresponded to the melting point of [Tri][MS]. As for the [Tri][MS]/Nafion membrane-7 $\mathrm{h}$, the endothermic peak representing the free [Tri][MS] melting was not found, which indicated that [Tri][MS] and Nafion membrane fully interacted with each other. However, the endothermic peak representing the free [Tri][MS] melting was found in the [Tri][MS]/Nafion membrane-36 $\mathrm{h}$ indicating that the free [Tri][MS] remained inside the membrane. These free [Tri][MS] can improve the ion conductivity of membrane [8].

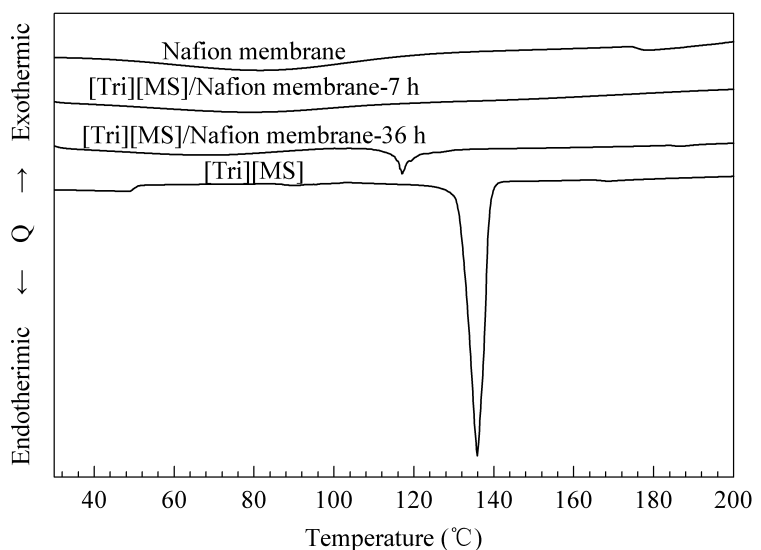

Figure 5. DSC thermograms for pure [Tri][MS] and [Tri][MS]/Nafion membranes

\subsection{Ionic conductivity}

During 140 to $190{ }^{\circ} \mathrm{C}$, the [Tri][MS] was in melt state. The ionic conductivity $(\sigma)$ data of the [Tri][MS]/Nafion membrane and pure [Tri][MS] under no humidification were shown in Figure 6. The curves displayed an increase in ionic conductivity with the increase of temperature in all cases. And [Tri][MS] exhibited high conductivity with $18.60 \mathrm{mS} \cdot \mathrm{cm}^{-1}$ at $140{ }^{\circ} \mathrm{C}$ and $36.51 \mathrm{mS} \cdot \mathrm{cm}^{-1}$ at $190^{\circ} \mathrm{C}$ while higher than Nafion membrane $\left(10^{-4}-10^{-8} \mathrm{~S} \cdot \mathrm{cm}^{-1}\right)$ under the dry condition [34].

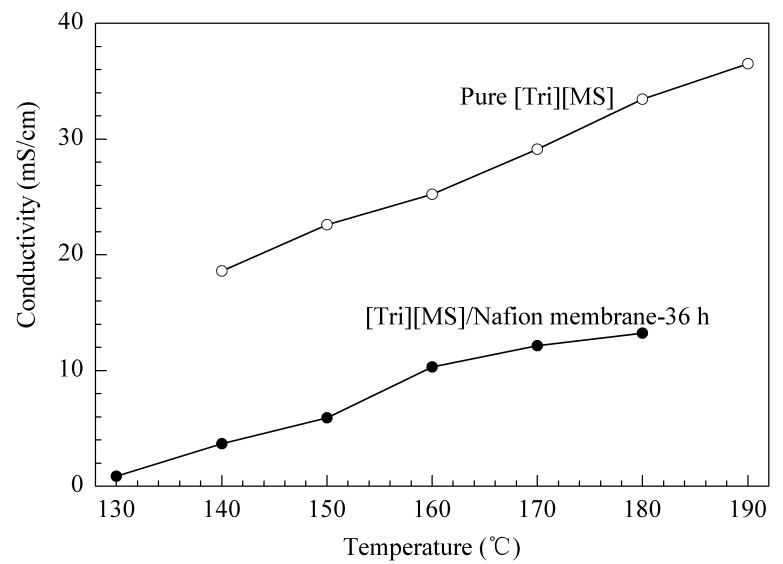

Figure 6. Variation of the ionic conductivity of pure [Tri][MS] and [Tri][MS]/Nafion membrane-36 $\mathrm{h}$ at different temperatures

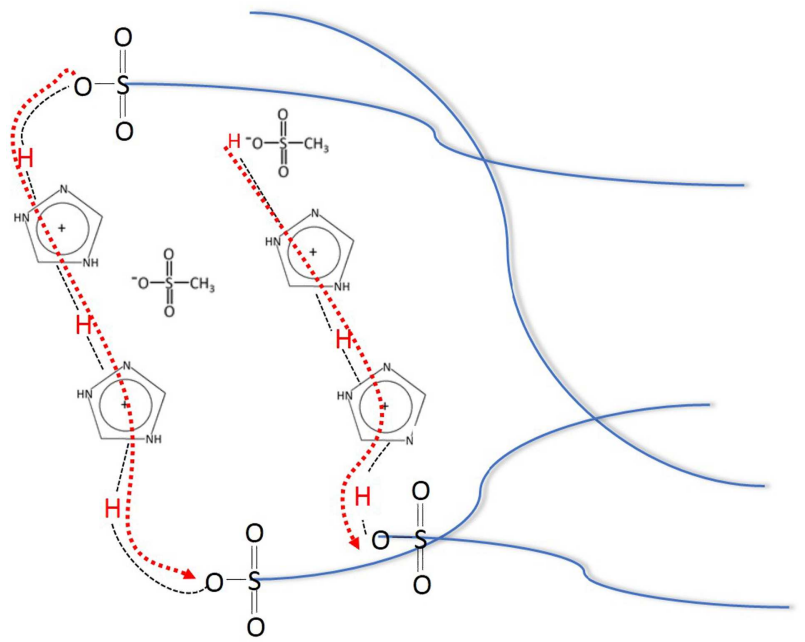

Figure 7. Hypothesis of ion conduction in [Tri][MS]-based membrane

Table 1. Ionic conductivity of different PILs/Nafion membrane

\begin{tabular}{|c|c|c|c|c|}
\hline Polymers & $\begin{array}{c}\text { Ion } \\
\text { source }\end{array}$ & $\begin{array}{l}\text { IL content } \\
(\mathrm{wt} \%)\end{array}$ & $\begin{array}{c}\text { onductivity }\left(\mathrm{mS} \cdot \mathrm{cm}^{-1}\right) / \\
\text { temperature }\left({ }^{\circ} \mathrm{C}\right)\end{array}$ & Ref. \\
\hline \multirow{5}{*}{ Nafion } & {$[$ Tri] $[\mathrm{MS}]$} & 25 & $3 / 180$ & this work \\
\hline & BMIm-TFSI & 7 to 14.5 & 0.84 to $3.58 / 160$ & [36] \\
\hline & BMIm-BF 4 & 8 to 54 & $1.9 / 130$ & [16] \\
\hline & S-POSS & 17 to 24 & 3 to $5 / 150$ & [37] \\
\hline & AA-TFA-MS-TF- & 19 to 42 & 1 to $20 / 120$ & [38] \\
\hline
\end{tabular}

BMIm-TFSI: 1-butyl-3-methylimidazolium bis (trifluoromethanesul-

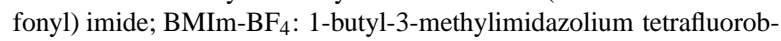
orate; S-POSS: sulfonated polyhedral oligomeric silsequioxane; AA-: acetic acid; TFA-: triethylammonium; MS-: sulfonic acid; TF-: triethylammonium. Examples of Nafion-based polymer membranes by impregnation containing IL: ion sources, IL contents and proton conductivities

In addition, below the melting point of [Tri][MS] $\left(136{ }^{\circ} \mathrm{C}\right)$, the ionic conductivity of the [Tri][MS]/Nafion membrane-36 $\mathrm{h}$ exhibited $0.31 \mathrm{mS} \cdot \mathrm{cm}^{-1}$ at $110^{\circ} \mathrm{C}$, $0.36 \mathrm{mS} \cdot \mathrm{cm}^{-1}$ at $120^{\circ} \mathrm{C}$ and $0.87 \mathrm{mS} \cdot \mathrm{cm}^{-1}$ at $130^{\circ} \mathrm{C}$. With the temperature increased, the [Tri][MS]/Nafion membrane exhibited higher ionic conductivity with $3.67 \mathrm{mS} \cdot \mathrm{cm}^{-1}$ at $140{ }^{\circ} \mathrm{C}$ and $13.23 \mathrm{mS} \cdot \mathrm{cm}^{-1}$ at $180^{\circ} \mathrm{C}$. The reason for the higher ionic conductivity above $136^{\circ} \mathrm{C}$ was that the existence of $\pi$-conjugated system in the melted [Tri][MS] facilitating to conduct proton. As we all know, the water-swelled electrolyte membrane has two typical mechanisms of proton conduction, namely, proton hopping (Grotthuss mechanisms) and diffusion (vehicular mechanisms). W. Ogihara and M. Yoshizawa [35] reported that the vehicular mechanisms should mainly govern the proton conduction in $\mathrm{C}_{2} \mathrm{H}_{3} \mathrm{~N}_{3}$ $\mathrm{CH}_{3} \mathrm{SO}_{3} \mathrm{H}$ system because that in this system obeyed the VFT equation. So, proton transport might occur predominantly by the same mechanism in the [Tri][MS]/Nafion membrane- $36 \mathrm{~h}$. The dissociated proton was mainly transferred by 1,2,4-triazolium via vehicular mechanisms and the hypothesis of ion conduction in the [Tri][MS]-based membrane was given in Figure 7. Besides, Table 1 shows the ionic conductivity of different PILs/Nafion membrane by the same way of impregnation. We could find that the low content of 
PILs about 7 to $30 \mathrm{wt} \%$ mainly resulted in the low ionic conductivity under the high temperature and no-humidification conditions. But from the data in Table 1, we still hold that the [Tri][MS]/Nafion systems had some merits under the high temperature and no-humidification conditions. This point could be proved by the performance of fuel cell below.

\subsection{Electrochemical analysis}

The $\mathrm{CV}$ and the ORR curves of Pt/C electrode and the $\mathrm{Pt} / \mathrm{C}$ electrode dyed with [Tri][MS] were measured to determine the ORR activity and selectivity of the $\mathrm{Pt} / \mathrm{C}$ catalyst dyed with [Tri][MS]. From Figure 8(a), we can clearly see that the activity area of $\mathrm{Pt} / \mathrm{C}$ catalyst decreased sharply when the electrode was dyed with [Tri][MS] and the oxidation and reduc-

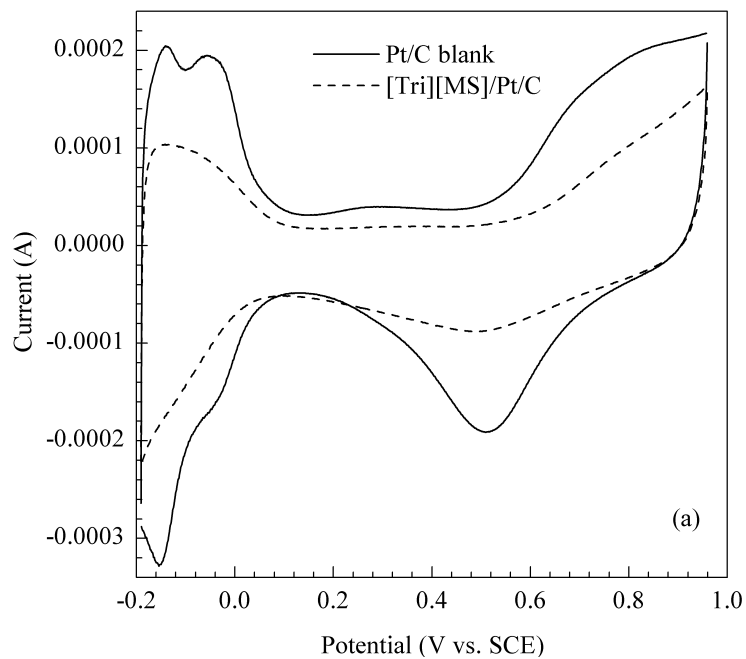

tion of Pt became not obvious. To demonstrate four-electron selectivity of $\mathrm{Pt} / \mathrm{C}$ catalyst dyed with [Tri][MS], the hydrogen peroxide yield $\mathrm{H}_{2} \mathrm{O}_{2}(\%)$ was calculated. And the hydrogen peroxide yield $\mathrm{H}_{2} \mathrm{O}_{2}(\%)$ in ORR and the total electrontransfer number $(n)$ were calculated by the following equation [39].

$$
\begin{gathered}
\mathrm{H}_{2} \mathrm{O}_{2} \text { yield }(\%)=\frac{2 I_{\mathrm{r}}}{N\left|I_{\mathrm{d}}\right|+I_{\mathrm{r}}} \times 100 \% \\
n=4-2 \times \frac{\mathrm{H}_{2} \mathrm{O}_{2} \text { yield }(\%)}{100}
\end{gathered}
$$

where, $N$ was the RRDE collection efficiency, and it was determined to be 0.37 herein. $I_{\mathrm{r}}$ was the ring current as a function of applied potential and $I_{\mathrm{d}}$ was the disk current against applied potential.

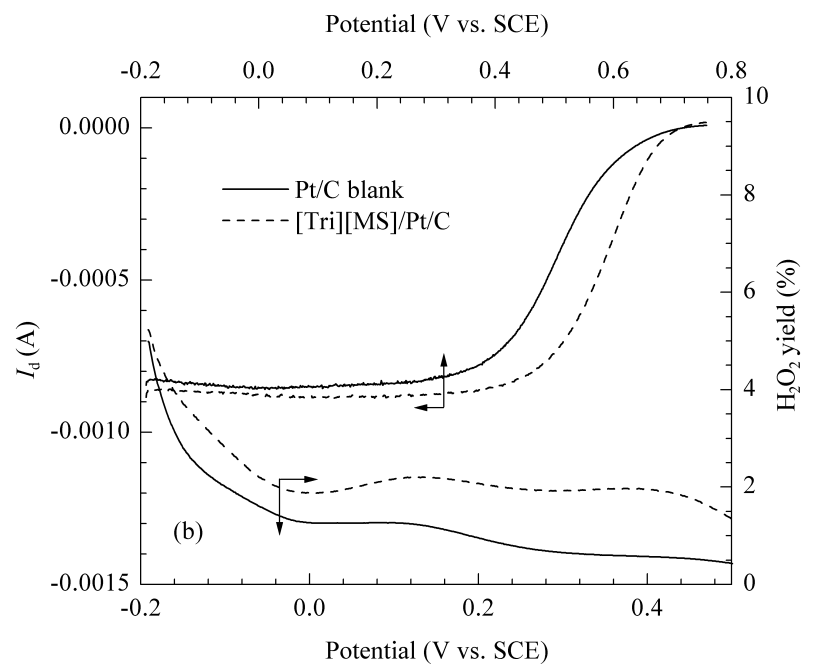

Figure 8. (a) $\mathrm{CV}$ curves of Pt/C electrodes dyed with [Tri][MS], in comparison with blank Pt/C; (b) ORR activity and $\mathrm{H}_{2} \mathrm{O}_{2}$ yield of a blank Pt/C electrode and a Pt/C electrode dyed with [Tri][MS]

ORR activity and four-electron selectivity data of Pt/C electrode and the Pt/C electrode dyed with [Tri][MS] were shown in Figure 8(b). While [Tri][MS] led to a declination in the ORR activity of Pt/C electrode dyed with [Tri][MS], resulting in a negative shift in the ORR onset potential when compared with $\mathrm{Pt} / \mathrm{C}$. Meanwhile, the $\mathrm{H}_{2} \mathrm{O}_{2}$ yields on $\mathrm{Pt} / \mathrm{C}$ catalyst dyed with [Tri][MS] exhibited a small growth with $0.96 \%$ at $0.4 \mathrm{~V}$ compared with $2.07 \%$ on $\mathrm{Pt} / \mathrm{C}$. And $n$ values were higher than 3.93 from $-0.1 \mathrm{~V}$ to $0.6 \mathrm{~V}$ (vs. SCE) toward oxygen reduction via four-electron reduction to $\mathrm{H}_{2} \mathrm{O}$. This indicated that, the Pt/C catalyst dyed with [Tri][MS] provided few active sites for oxygen reduction, however, mainly to $\mathrm{H}_{2} \mathrm{O}_{2}$ on a four-electron path. It might be caused by the strong absorption of [Tri][MS] on the surface of Pt covering the active site of $\mathrm{H}$ on the surface of Pt. All these results showed that [Tri][MS] had a strong poisoning effect on the catalyst. The bad compatibility between [Tri][MS] and the $\mathrm{Pt} / \mathrm{C}$ catalyst would be adverse to the fuel cell performance.

\subsection{Fuel cell performance}

A single cell membrane electrode assembly (MEA) with the $[$ Tri] $[\mathrm{MS}] /$ Nafion membrane- $36 \mathrm{~h}$ and the platinized ionomer-PBI gas diffusion electrodes was tested at 140 and $150{ }^{\circ} \mathrm{C}$ under anhydrous conditions. As shown in Figure 9, the open circuit voltage (OCV) of the [Tri][MS]/Nafion membrane was up to $0.741 \mathrm{~V}$ at the temperature of 140 and $150{ }^{\circ} \mathrm{C}$ while the Nafion membrane was lower than $0.6 \mathrm{~V}$ at the same condition. In addition, the highest power density of the [Tri][MS]/Nafion membrane was $3.20 \mathrm{~mW} \cdot \mathrm{cm}^{-2}$ at $140{ }^{\circ} \mathrm{C}$ and $4.90 \mathrm{~mW} \cdot \mathrm{cm}^{-2}$ at $150^{\circ} \mathrm{C}$, which was much higher than those of the Nafion membrane with $1.00 \mathrm{~mW} \cdot \mathrm{cm}^{-2}$ at $140{ }^{\circ} \mathrm{C}$ and $1.06 \mathrm{~mW} \cdot \mathrm{cm}^{-2}$ at $150^{\circ} \mathrm{C}$. Besides, the highest current density of the [Tri][MS]/Nafion membrane could be up to $36.6 \mathrm{~mA} \cdot \mathrm{cm}^{-2}$ at $150{ }^{\circ} \mathrm{C}$ and $29.4 \mathrm{~mA} \cdot \mathrm{cm}^{-2}$ at $140^{\circ} \mathrm{C}$. These results demonstrated that the [Tri] $[\mathrm{MS}] / \mathrm{Nafion}$ membrane was promising to be used at high temperatures and without humidification. However, considering the bad compatibility of [Tri][MS] with Nafion membrane, the [Tri][MS] doping levels in the [Tri][MS]/Nafion membrane was limited and it could not form a continuous ionic channels through the membrane, restricting the proton transport and finally the fuel cell performance. Besides, the [Tri][MS] had a strong poisoning 

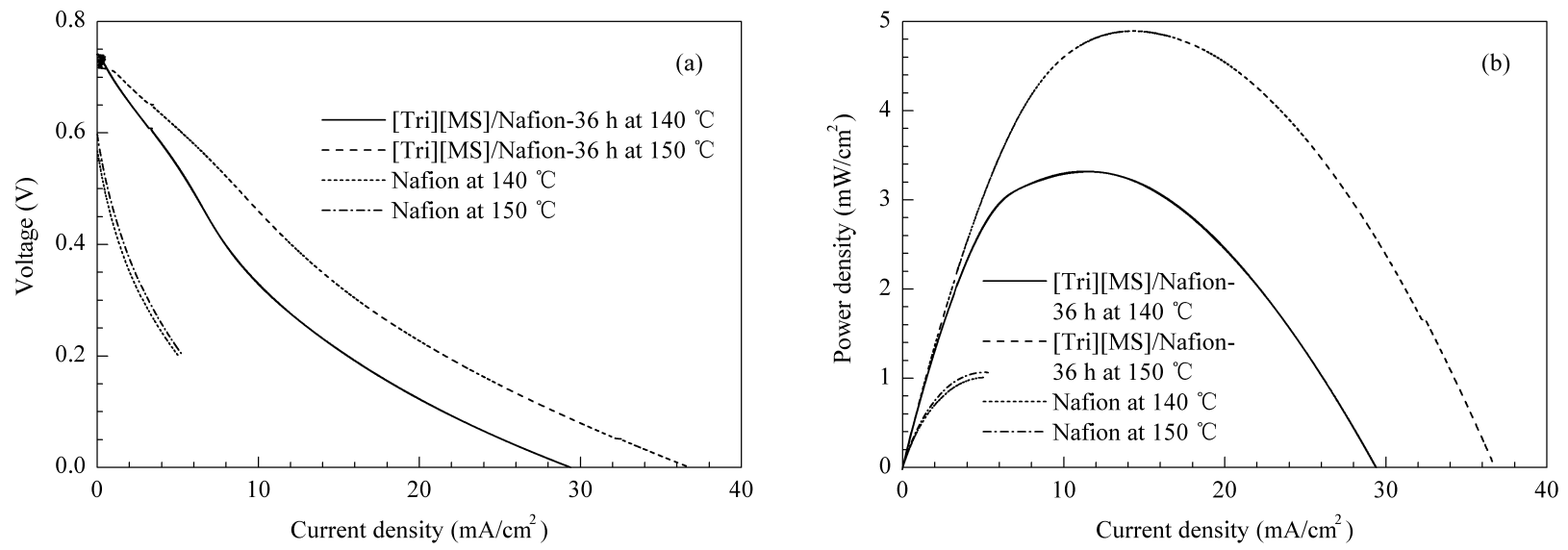

Figure 9. Fuel cell characteristics for [Tri][MS]/Nafion membrane-36 h under anhydrous condition at 140 and $150{ }^{\circ} \mathrm{C}$

effect on the Pt/C leading to the decrease of catalyst activity, which was another reason restricting the output performance of the single fuel cell.

\section{Conclusions}

A new ionic conductor, 1,2,4-triazolium methanesulfonate ([Tri][MS]) was successfully synthesized and it showed good thermal stability both in $\mathrm{N}_{2}$ and air atmosphere and high ionic conductivity of $0.036 \mathrm{~S} \cdot \mathrm{cm}^{-1}$ at $190^{\circ} \mathrm{C}$. In addition, the [Tri][MS] was first applied to modify Nafion membrane to prepare [Tri][MS]/Nafion composite membrane by impregnation method under high temperature. The composite membrane exhibited excellent chemical stability in air atmosphere and high conductivity of $13.23 \mathrm{mS} \cdot \mathrm{cm}^{-1}$ at $180^{\circ} \mathrm{C}$. The highest power density of the fuel cell with the composite membrane reached $3.20 \mathrm{~mW} \cdot \mathrm{cm}^{-2}$ at $140{ }^{\circ} \mathrm{C}$ and $4.90 \mathrm{~mW} \cdot \mathrm{cm}^{-2}$ at $150^{\circ} \mathrm{C}$, while the Nafion membrane was $1.00 \mathrm{~mW} \cdot \mathrm{cm}^{-2}$ at $140{ }^{\circ} \mathrm{C}$ and $1.06 \mathrm{~mW} \cdot \mathrm{cm}^{-2}$ at $150^{\circ} \mathrm{C}$. All in all, the [Tri][MS] showed great potential to be applied as the ionic conductor for HT-PEMFCs. However, the fuel cell performance was not good enough due to the bad compatibility of [Tri][MS]/Nafion composite membrane and $\mathrm{Pt} / \mathrm{C}$ catalyst. As a result, other more suitable polymer substrate and catalyst should be explored to improve the compatibility with [Tri][MS] and to further enhance the fuel cell performance.

\section{Acknowledgements}

This work was financially supported by the National Basic Research Program of China (973 Program, Grant 2012CB215504) and the National Natural Science Foundation of China (21203191 and 21306190).

\section{References}

[1] Weiss-Ungethum J, Burger I, Schmidt N, Linder M, Kallo J. Int J Hydrogen Energ, 2014, 39(11): 5931

[2] Zhang H W, Shen P K. Chem Soc Rev, 2012, 41(6): 2382

[3] Lu S, Xiu R, Xu X, Liang D, Wang H, Xiang Y. J Membr Sci, 2014, 464: 1
[4] Eguizábal A, Lemus J, Pina M P. J Power Sources, 2013, 222: 483

[5] Shao Z G, Joghee P, Hsing I M. J Membr Sci, 2004, 229(1-2): 43

[6] Dai W, Wang H J, Yuan X Z, Martin J J, Yang D J, Qiao J L, Ma J X. Int J Hydrogen Energy, 2009, 34(23): 9461

[7] Yu S M, Yan F, Zhang X W, You J B, Wu P Y, Lu J M, Xu Q F, Xia X W, Ma G L. Macromolecules, 2008, 41(10): 3389

[8] Liu S, Zhou L, Wang P J, Zhang F F, Yu S C, Shao Z G, Yi B L. Acs Appl Mater Interf, 2014, 6(5): 3195

[9] Li J, Li X J, Zhao Y, Lu W T, Shao Z G, Yi B L. ChemSusChem, 2012, 5(5): 896

[10] Kikuchi K, Tsuchitani S. J Appl Phys, 2009, 106(5): 053519

[11] Neves L A, Benavente J, Coelhoso I M, Crespo J G. J Membr Sci, 2010, 347(1-2): 42

[12] Martinez de Yuso M V, Neves L A, Coelhoso I M, Crespo J G, Benavente J, Rodriguez-Castellon E. Fuel Cells, 2012, 12(4): 606

[13] Lee S Y, Ogawa A, Kanno M, Nakamoto H, Yasuda T, Watanabe M. J Am Chem Soc, 2010, 132(28): 9764

[14] Noda A, Susan A B H, Kudo K, Mitsushima S, Hayamizu K, Watanabe M. J Phys Chem B, 2003, 107(17): 4024

[15] Gao J, Guo Y, Wu B, Qi L, Li B, Liu J, Wang Z, Liu W, Gu J, Zou Z. J Power Sources, 2014, 251: 432

[16] Doyle M, Choi S K, Proulx G. J Electrochem Soc, 2000, 147(1): 34

[17] Yang J, Che Q, Zhou L, He R, Savinell R F. Electrochim Acta, 2011, 56(17): 5940

[18] Celik S U, Bozkurt A. Polym Advan Technol, 2014, 25(2): 191

[19] Sood R, Iojoiu C, Espuche E, Gouanve F, Gebel G, MendilJakani H, Lyonnard S, Jestin J. J Phys Chem C, 2014, 118(26): 14157

[20] Zhou Z, Liu R, Wang J H, Li S W, Liu M L, Brédas J L. J Phys Chem A, 2006, 110(7): 2322

[21] Li S W, Zhou Z, Zhang Y L, Liu M L, Li W. Chem Mater, 2005, 17(24): 5884

[22] Luo J, Hu J, Saak W, Beckhaus R, Wittstock G, Vankelecom I F J, Agert C, Conrad O. J Mater Chem, 2011, 21(28): 10426

[23] Baek J S, Park J S, Sekhon S S, Yang T H, Shul Y G, Choi J H. Fuel Cells, 2010, 10(5): 762

[24] Li M Q, Scott K. Electrochim Acta, 2010, 55(6): 2123

[25] Sasa D, Sinirlioglu D, Muftuoglu A E, Eren F, Celik S U, Bozkurt A. J Polym Res, 2013, 20(12): 313 
[26] Pu H, Wang L, Pan H, Wan D. J Polym Sci Pol Chem, 2010, 48(10): 2115

[27] Aslan A, Celik S U, Sen U, Haser R, Bozkurt A. Electrochim Acta, 2009, 54(11): 2957

[28] Chowdhury A, Thynell S T. Thermochim Acta, 2007, 466(1-2): 1

[29] Celik S U, Akbey U, Bozkurt A, Graf R, Spiess H W. Macromol Chem Phys, 2008, 209(6): 593

[30] Billes F, Endredi H, Keresztury G. J Mol Struc-theochem, 2000, 530(1-2): 183

[31] Deligöz H, Yilmazoğlu M. J Power Sources, 2011, 196(7): 3496

[32] Surowiec J, Bogoczek R. J Therm Anal Calorim, 1988, 33(4): 1097
[33] Lage L G, Delgado P G, Kawano Y. J Therm Anal Calorim, 2004, 75(2): 521

[34] Tago T, Shibata H, Nishide H. Chem Commun, 2007(28): 2989

[35] Ogihara W, Kosukegawa H, Ohno H. Chem Commun, 2006(34): 3637

[36] Mistry M K, Subianto S, Choudhury N R, Dutta N K. Langmuir, 2009, 25(16): 9240

[37] Martinez M, Molmeret Y, Cointeaux L, Iojoiu C, Leprêtre J C, El Kissi N, Judeinstein P, Sanchez J Y. J Power Sources, 2010, 195(18): 5829

[38] Subianto S, Mistry M K, Choudhury N R, Dutta N K, Knout R. Acs Appl Mater Interf, 2009, 1(6): 1173

[39] Wu G, Chen Z, Artyushkova K, Garzon F H, Zelenay P. ECS Trans, 2008, 16(2): 159 